\title{
Activity of Encapsulated Lactobacillus bulgaricus in Alginate-whey Protein Microspheres
}

\author{
Meng-Yan Chen ${ }^{1}$, Wei Zheng ${ }^{1}$, Qiu-Yue Dong ${ }^{1}$, Zhen-Hua Li $^{1}$, Lu-E Shi ${ }^{1}$ and Zhen-Xing \\ Tang $1,2,3, *$ \\ ${ }^{1}$ College of Life and Environmental Sciences; Hangzhou Normal University; Hangzhou, Zhejiang - \\ China. ${ }^{2}$ Department of Food Science; Anqing Vocational \& Technical College; Anqing, Anhui - China. \\ ${ }^{3}$ Date Palm Research Center; King Faisal University; Al-hasa - Saudi Arabia
}

\begin{abstract}
In this work, alginate-whey protein was used as wall materials for encapsulating Lactobacillus delbrueckii subsp. bulgaricus (L. bulgaricus). The characteristics of encapsulated and free L. bulgaricus showed that the free L. bulgaricus lost viability after 1 min exposure to simulated gastric fluid (SGF) at $p H 2.0$ and 2.5. However, the viability of encapsulated L. bulgaricus did not decrease in SGF at pH 2.5 for $2 \mathrm{~h}$ incubation. The viable numbers of encapsulated $\mathrm{L}$. bulgaricus decreased less than 1.0 log unit for $2 \mathrm{~h}$ incubation in SGF at pH 2.0. For bile stability, only 1.2 log units and 2.0 log units viability of the encapsulated $\mathrm{L}$. bulgaricus was lost in 1 and $2 \%$ bile for 1 h exposure, respectively, compared with no survival of free L. bulgaricus under the same conditions. Encapsulated L. bulgaricus was completely released from the microspheres in simulated intestinal fluid (SIF, pH 6.8) in $3 \mathrm{~h}$. The viability of the encapsulated L. bulgaricus retained more $8.0 \mathrm{log} \mathrm{CFU} / \mathrm{g}$ after stored at $4^{\circ} \mathrm{C}$ for four weeks. However, for free L. bulgaricus, only around $3.0 \mathrm{log} \mathrm{CFU} / \mathrm{mL} \mathrm{was}$ found at the same storage conditions. Results showed that the encapsulation could improve the stability of L. bulgaricus.
\end{abstract}

Key words: Encapsulation, Alginate, Whey protein, Probiotics, Stability

\section{INTRODUCTION}

Several studies have shown that the probiotics play an important role in human health; they can prevent diarrhea, balance the intestinal microflora, stimulate of the immune system, have anticarcinogenic properties and lactose intolerance (Shah 2007). FAO has recommended that the least viability of probiotics should be at $10^{7} \mathrm{CFU} / \mathrm{g}$ of product at the time of consumption. The biggest problem in probiotics application is its sensitivity to environment conditions (Carvalho et al. 2004). Hence, protecting the viability of probiotics is one of the premises of its application.

Encapsulation is one of most effective methods that improve the viability and stability of probiotic bacteria (Gbassi et al. 2009; Heidebach et al.
2010; Dolly et al. 2011). Alginate is by far the most widely used wall material for encapsulation. However, encapsulation of probiotic bacteria in alginate microspheres was not able to protect the organisms effectively from high acidic environment (Sultana et al. 2000; Krasaekoopt et al. 2003; Dong et al. 2013; Pan et al. 2013; Shi et al. $2013 \mathrm{a}, \mathrm{b})$. Whey protein or denatured whey protein is another extensively used as wall material for the encapsulation of probiotics. Denatured whey protein can be obtained through heating whey protein solution (Anandharamakrishnan et al. 2007; Tang et al. 2013). The application of polysaccharide-protein matrix for probiotics encapsulation is a relatively new strategy and can be seen as a promising alternative approach developed for probiotic

*Author for correspondence: tangzhenxing@126.com 
encapsulation. In this study, extrusion technique was employed for the encapsulation of $L$. bulgaricus with wall material combinations of denatured whey protein and sodium alginate. Characteristics of encapsulated L. bulgaricus were investigated and compared with those of free $L$. bulgaricus.

\section{MATERIAL AND METHODS}

\section{Cell culture Preparation}

Lactobacillus bulgaricus was provided by Hangzhou Wahaha Group Co Ltd. (ZhejiangChina) as a $25 \%$ glycerol stock in MRS broth (Difco, Michigan, USA) at $-80^{\circ} \mathrm{C}$. All the glass-wares used in this study were sterilized at $121^{\circ} \mathrm{C}$ for $15 \mathrm{~min}$. The culture was activated in MRS broth at $37^{\circ} \mathrm{C}$ and propagated two times prior to use in the experimental trials. The fresh culture was prepared by adding $1 \%$ inoculum to MRS broth and incubated at $37^{\circ} \mathrm{C}$ for overnight. The cells were harvested by centrifugation at $3,000 \mathrm{~g}$ at $4^{\circ} \mathrm{C}$ for $10 \mathrm{~min}$. After the removal of supernatant, the cells were washed with sterile $0.85 \%(\mathrm{w} / \mathrm{v})$ sodium chloride solution.

\section{Encapsulation of $L$. bulgaricus}

Whey protein powder was mixed with sterile distilled water. The solution was stirred gently using a magnetic stirrer to dissolve the whey protein prior to heat treatment. In order to denature the whey protein, the solution was kept at $80^{\circ} \mathrm{C}$ for $30 \mathrm{~min}$ in a water bath (Tang et al. 2013). Alginate-whey protein microspheres were made using an Inotech Encapsulator IER-50 (Inotech Biosystems Intl. Inc.) by extruding a mixture containing $L$. bulgaricus suspended in sodium alginate solution and de-natured whey protein into $0.1 \mathrm{M} \mathrm{CaCl}_{2}$ solution while gently stirring with a magnetic bar. The microspheres were prepared using a $450 \mu \mathrm{m}$ nozzle. The resulting microspheres were allowed to harden in the $\mathrm{CaCl}_{2}$ solution for $30 \mathrm{~min}$, rinsed with distilled water, filtered, and sealed in sterilized conical tubes for storage at $4^{\circ} \mathrm{C}$.

\section{Survival assay and numeration of encapsulated and free $L$. bulgaricus}

pH stability: Microspheres or free L. bulgaricus were added to test tubes containing SGF $(0.2 \%$, $\mathrm{w} / \mathrm{v}, \mathrm{NaCl}$ at $\mathrm{pH} 2.5$ or $\mathrm{pH} 2.0$ ) and incubated at $37^{\circ} \mathrm{C}$ for $0,10,30,60,90$ and $120 \mathrm{~min}$. At pre- determined time, wet microspheres were removed from the SGF, washed with saline solution, dispersed and broken down in SIF $(50 \mathrm{~mm}$ $\left.\mathrm{KH}_{2} \mathrm{PO}_{4}\right) \mathrm{pH}$ 6.8. The survival of encapsulated or free L. bulgaricus was immediately assayed (Pan et al. 2013; Shi et al. 2013 a, b).

Bile stability: Microspheres or free L. bulgaricus suspension were added to test tubes containing simulated bile ( 1 or $2 \%, \mathrm{w} / \mathrm{v})$ porcine bile extract (Sigma-Aldrich) and incubated at $37^{\circ} \mathrm{C}$ for 1 and $2 \mathrm{~h}$. After pre-determined time, the beads were washed with saline solution. Microspheres were dissolved in SIF ( $\mathrm{pH}$ 6.8). The viability of encapsulated or free $L$. bulgaricus was immediately assayed as above.

Release profile: Microsphere samples were added to SIF solution and incubated at $37^{\circ} \mathrm{C}$ with shaking at $100 \mathrm{rpm} / \mathrm{min}$. At predetermined time points, $100 \mu \mathrm{L}$ of this solution was taken out and immediately assayed for the activity. The same volume of the fresh medium was added to replace the volume of the withdrawn samples. The cumulative amount of released L. bulgaricus was plotted against the time (Pan et al. 2013; Shi et al. $2013 \mathrm{a}, \mathrm{b})$.

Storage stability: Microspheres or free $L$. bulgaricus were stored at $4^{\circ} \mathrm{C}$. At pre-determined time points, samples were taken out for activity measurement. Total viable counts of $L$. bulgaricus were determined by a pour plate method using MRS agar after serial 10-fold dilutions in saline solution. Plates were incubated at $37^{\circ} \mathrm{C}$ for $48 \mathrm{~h}$ (Pan et al. 2013; Shi et al. 2013 a, b).

\section{Statistical analysis}

All the experiments were repeated at least three times and the results were presented in mean value \pm standard deviation (SD). Statistical analysis was performed using Original 8.0 for Windows. Student's t test was used to compare the significance of differences. The differences were considered significant at the level of $\mathrm{P}<0.05$.

\section{RESULTS AND DISCUSSIONS}

\section{Preparation of encapsulated $L$. bulgaricus microspheres}

One of necessary pre-requisite for encapsulation method is high encapsulation yield. The initial number of viable $L$. bulgaricus in aqueous suspension used to prepare the microspheres was about $10.01 \log \mathrm{CFU} / \mathrm{mL}$. After encapsulation, the 
number of viable cells recovered in $\mathrm{pH} 6.8 \mathrm{SIF}$ was $9.98 \log \mathrm{CFU} / \mathrm{g}$. The encapsulation yield of $L$. bulgaricus in alginate-whey protein microspheres was close to $100 \%$. It indicated that this encapsulation process led to a high encapsulation yield. High encapsulation efficiency of $96 \%$ was also reported for the encapsulation of probiotic yeasts in alginate-whey protein microspheres (Hébrard et al. 2010). Therefore, it appeared that alginate-whey protein matrices had a good compatibility with functional biological substances, including L. bulgaricus.

The size of alginate-based microspheres can be affected by various factors such as nozzle size, polymer concentration, hardening time in calcium chloride, initial cell concentration, etc (Chandramouli et al. 2004; Dong et al. 2013; Shi et al. $2013 \mathrm{a}, \mathrm{b}$ ). In this work, the, nozzle size was $450 \mu \mathrm{m}$. Alginate-whey protein microspheres with diameter around $800 \mu \mathrm{m}$ and a spherical shape were obtained (results not shown). In the case of encapsulation for food application, the size of the microspheres is an important factor. Large microspheres can adversely affect the texture of food after supplementation by causing coarseness; small microspheres may not give sufficient protection. Alginate-based microspheres often with between 1.0 to $3.0 \mathrm{~mm}$ are obtained, which are too large for many food applications (Sheu and Marshall 1993; Hansen et al. 2002; Muthukumarasamy et al. 2006; Dong et al. 2013; Shi et al. $2013 \mathrm{a}, \mathrm{b}$ ). In the present study, alginatewhey protein microspheres were below $1.0 \mathrm{~mm}$. It might not produce enough detrimental effect on the texture of food. Smaller microspheres could be obtained when smaller nozzle size was used.

\section{Stability of encapsulated $L$. bulgaricus in SGF}

One of major problems in efficacy of probiotic food is low survival of the cells in the gastric $\mathrm{pH}$. Encapsulated and free L. bulgaricus were tested for the survival under simulated gastric $\mathrm{pH}$ of 2.0 and 2.5 (Fig. 1). It was found that the encapsulation could improve the $\mathrm{pH}$ tolerance of L. bulgaricus. The numbers of encapsulated cells did not decrease in SGF $\mathrm{pH}$ at 2.5 for $2 \mathrm{~h}$ incubation. The viable count of the encapsulated L. bulgaricus decreased less than $1.0 \log$ unit for 2 $\mathrm{h}$ incubation in $\mathrm{pH}$ 2.0 SGF. However, free cells of $L$. bulgaricus were extremely sensitive to acidic environments and were not detectable after $1 \mathrm{~min}$ exposure to $\mathrm{SGF}$ at $\mathrm{pH} 2.5$ and 2.0 (results not shown). These results agreed with several earlier reports. Chandramouli et al. (2004) found that the viable numbers of $L$. acidophilus encapsulated in alginate microspheres was significant increased in SGF at $\mathrm{pH}$ 2.0. Encapsulated L. acidophilus in alginate microspheres survived better after sequential incubation in simulated gastric and intestinal juices (Krasaekoopt et al. 2004). Higher survival was also reported when the encapsulated lactobacilli in alginate microspheres were incubated in SGF (Lee et al. 2004).

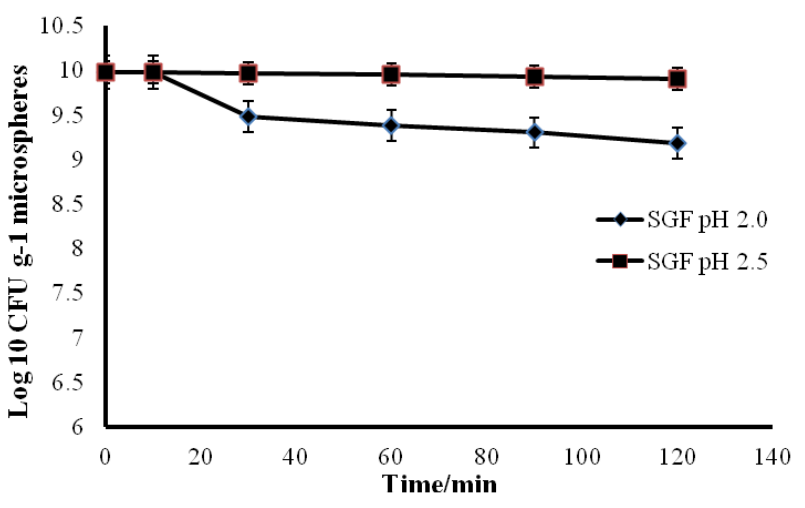

Figure 1 - Survival of encapsulated Lactobacillus bulgaricus in $\mathrm{pH}$ 2.0 SGF and $\mathrm{pH} 2.5$ SGF.

\section{Stability of encapsulated $L$. bulgaricus in bile salt stability}

The results of free and encapsulated L. bulgaricus subjected to different concentrations of bile salts (1 and 2\%) are shown in Table 1. It indicated a similar trend for viability of encapsulated and free L. bulgaricus in bile salt. From the initial count of $10.01 \log \mathrm{CFU} / \mathrm{mL}$, no survival was found in 1 and $2 \%$ bile salt after $1 \mathrm{~h}$ exposure. The decrease rate was lower for the encapsulated L. bulgaricus. Table 1 illustrated around $2.0 \mathrm{log}$ and $3.0 \mathrm{log}$ reduction of $L$. bulgaricus after $2 \mathrm{~h}$ incubation in 1 and $2 \%$ bile salt concentrations, respectively. The numbers declined more as the bile concentration and incubation time increased. The sensitivity of many probiotics strains to bile concentrations encountered in the human gastro-intestinal tract has been reported by several authors (Chung et al. 1999; Amor et al. 2002; Picot \& Lacroix 2004). Clark and Martin (1994) observed 5.0 log reductions in viable cell counts of $B$. adolescentis in $2 \%$ bile solution after $12 \mathrm{~h}$ incubation at $37^{\circ} \mathrm{C}$. Amor et al. (2002) found that the viability of $B$. lactis and $B$. adolescentis was more susceptible to the damaging effects of bile salts. In the present study, higher survival rate of the cells in alginate- 
whey protein microspheres after bile solution treatment was pre-requisite for providing the host with a beneficial health effect.

Table 1 - Survival of free and encapsulated $L$. bulgaricus after treatment in simulated bile concentrations of 1 and $2 \%$ for $1 \mathrm{~h}$ and $2 \mathrm{~h}(\log 10$ CFU/g microspheres).

\begin{tabular}{lccc}
\hline \multirow{2}{*}{ Condition/time } & \multicolumn{3}{c}{ Bile concentration (\%) } \\
\cline { 2 - 4 } & 0 & 1 & 2 \\
\hline $\begin{array}{l}\text { Free } \text { L. bulgaricus } \\
(1 \mathrm{~h})\end{array}$ & $10.01 \pm 0.13$ & 0 & 0 \\
$\begin{array}{l}\text { Encapsulated } L . \\
\text { bulgaricus }(1 \mathrm{~h})\end{array}$ & $9.98 \pm 0.12$ & $8.78 \pm 0.03$ & $7.98 \pm 0.08$ \\
$\begin{array}{l}\text { Free } \text { L. bulgaricus } \\
(2 \mathrm{~h})\end{array}$ & $10.01 \pm 0.08$ & 0 & 0 \\
$\begin{array}{l}\text { Encapsulated } L . \\
\text { bulgaricus }(2 \mathrm{~h})\end{array}$ & $9.96 \pm 0.14$ & $7.69 \pm 0.07$ & $7.03 \pm 0.15$ \\
\hline $\begin{array}{l}\text { Var } \\
\text { nayy }\end{array}$
\end{tabular}

Values shown are means \pm standard deviations $(\mathrm{n}=3)$. Means in the table differ significantly $(\mathrm{P}<0.05)$.

\section{Release of encapsulated L. bulgaricus in SIF}

The release of the cells from microcapsules in colon is essential for the growth and colonization of probiotics. Figure 2 illustrates the release of cells of the encapsulated L. bulgaricus in $\mathrm{pH} 6.8$ SIF. When encapsulated L. bulgaricus was placed into SIF at $\mathrm{pH} 6.8$, the microspheres began to swell and eventually disintegrated. For alginatewhey protein microspheres, the cells of $L$. bulgaricus released within $3 \mathrm{~h}$ and $70 \%$ of cell had already been released within $1 \mathrm{~h}$. Gunsaekaran et al. (2007) encapsulated caffeine using whey protein hydrogel and observed similar release profiles, in which a burst release of caffeine happened within $1 \mathrm{~h}$ at $\mathrm{pH}$ 7.5. At $\mathrm{pH} 6.8$, whey proteins are negatively charged, which may interact with the carboxyl group from the alginate molecules. This electrostatic repulsion also favors the dissociation of the gel network. It is well known that alginate gel formed through calcium ions is very rigid and only swells slowly at neutral $\mathrm{pH}$. Mandal et al. (2006) found that the release of cells progressed with increased incubation. A progressive release of viable cells from whey protein-based microcapsules in SIF was also reported by Picot and Lacroix (2004).

\section{Storage stability of encapsulated $L$. bulgaricus}

The storage stability of free and encapsulated $L$. bulgaricus during four weeks at $4^{\circ} \mathrm{C}$ is shown in Figure 3. The viability of the encapsulated $L$. bulgaricus was higher compared to free $L$. bulgaricus. The viability of free L. bulgaricus was from $10.01 \log \mathrm{CFU} / \mathrm{mL}$ to $9.93 \log \mathrm{CFU} / \mathrm{mL}$ after one week, and around $3.0 \log \mathrm{CFU} / \mathrm{mL}$ after four weeks. However, the number of encapsulated $L$. bulgaricus cells only decreased from $9.97 \mathrm{log}$ $\mathrm{CFU} / \mathrm{mL}$ to 8.37 after four weeks. The viability of encapsulated $L$. bulgaricus cells was fully preserved in one week. Therefore, encapsulation of L. bulgaricus in alginate-whey protein microspheres could improve the storage stability of free L. bulgaricus cells. Several studies that encapsulated bacteria in alginate-based microspheres reported better survival ability than non-encapsulated bacteria during the storage period (Truelstrup Hansen et al. 2002; Krasaekoopt et al. 2003; Pan et al. 2013; Shi et al. $2013 \mathrm{a}, \mathrm{b})$.

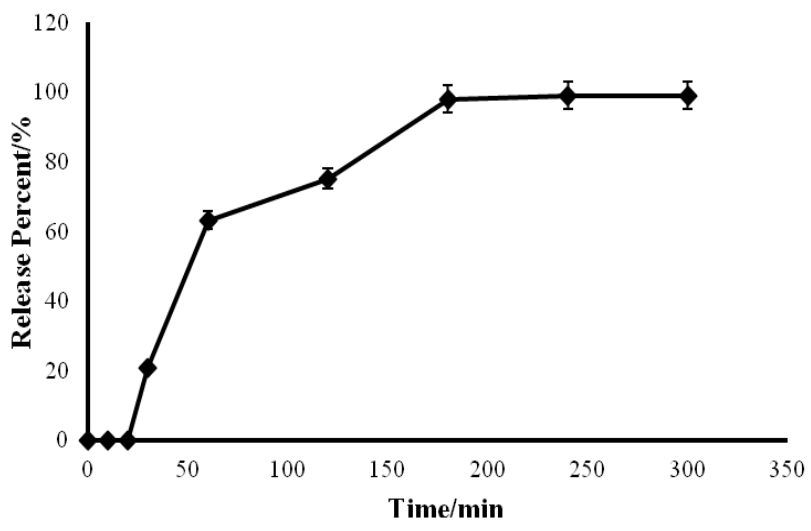

Figure 2 - Release profile of encapsulated Lactobacillus bulgaricus in $\mathrm{pH} 6.8 \mathrm{SIF}$.

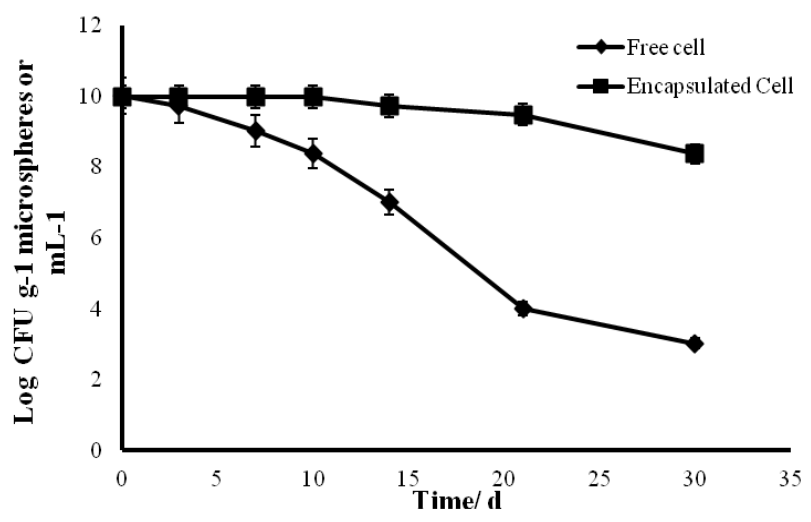

Figure 3 - Storage stability of free and encapsulated Lactobacillus bulgaricus at $4{ }^{\circ} \mathrm{C}$. 


\section{CONCLUSIONS}

\begin{abstract}
Alginate-whey protein microspheres encapsulating model L. bulgaricus were produced by extrusion method. Encapsulated microspheres had better survival ability after bile salt concentrations, and at low $\mathrm{pH}$, long storage time as compared to free cells. Encapsulated $L$. bulgaricus was released from the microspheres within a reasonable time so as to exert their beneficial effects. These findings demonstrated alginate-whey protein microspheres were effective wall carriers for probiotics encapsulation.
\end{abstract}

\section{ACKNOWLEDGEMENTS}

This study was financially supported by the Xinmiao Talent Program of Zhejiang Province (2013R421006).

\section{REFERENCES}

Amor KB, Breeuwer P, Rombouts P, Verbaarschot FM, Akkermans ADL, et al. Multiparametric flow cytometry and cell sorting for the assessment of viable, injured and dead bifidobacterium cells during bile salt stress. Appl Environ Microbiol. 2002; 68: 5209-5216.

Anandharamakrishnan C, Rielly CD, Stapley AGF. Effects of process variables on the denaturation of whey proteins during spray-drying. Drying Technol. 2007; 25: 799-807.

Carvalho AS, Silva J, Ho P, Teixeira P, Malcata FX, Gibbs P. Relevant factors for the preparation of freeze-dried lactic acid bacteria. Int Dairy J. 2004; 14: 835-847.

Chandramouli V, Kailaspathy K, Peiris P, Jones M. An improved method of microencapsulation and its evaluation to protect Lactobacillus spp. in simulated gastric conditions. J Microbiol Meth. 2004; 56: $27-$ 35.

Chung HS, Kim YB, Chun SL, Ji GE. Screening and selection of acid and bile resistant bifidobacteria. Int J Food Microbiol. 1999; 47: 25-32.

Clark PA, Martin JH. Selection of Bifidobacteria for use as dietary adjuncts in cultured dairy foods: IIITolerance to simulated bile concentrations of human small intestines. Cultured Dairy Products J. 1994; 29: $20-21$.
Dolly P, Anishaparvin A, Joseph GS, Anandharamakrishnan C. Microencapsulation of Lactobacillus plantarum (mtcc 5422) by sprayfreeze-drying method and evaluation of survival in simulated gastrointestinal conditions. $J$ Microencapsul 2011; 28: 568-574.

Dong QY, Chen MY, Xin Y, Qin XY, Chen Z, Shi LE, et al. Alginate-based and protein-based materials for probiotics encapsulation: A review. Int J Food Sci Technol. 2013; 48: 1339-1351.

Gbassi GK, Vandamme T, Ennahar S, Marchioni E. Microencapsulation of Lactobacillus plantarum spp. in an alginate matrix coated with whey proteins. Int $J$ Food Microbiol. 2009; 129: 103-105.

Gunasekaran S, Ko S, Xiao L. Use of whey proteins for encapsulation and controlled delivery applications. $J$ Food Eng. 2007; 83: 31-40.

Hansen LT, Allan-Wojtas PM, Jin YL, Paulson AT. Survival of Ca-alginate microencapsulated Bifidoacterium spp. in milk and simulated gastrointestinal conditions. Food Microbiol. 2002; 19:35-45.

Hébrard G, Hoffart V, Beyssac E, Cardot JM, Alric M, Subirade M. Coated whey protein/alginate microparticles as oral controlled delivery systems for probiotic yeast. J Microencapsul. 2010; 27: 292-302.

Heidebach T, Forst P, Kulozik U. Influence of caseinbased microencapsulation on freeze-drying and storage of probiotic cells. J Food Eng. 2010; 98:309316.

Krasaekoopt W, Bhandari B, Deeth H. Evaluation of encapsulation techniques of probiotics for yoghurt. Int Dairy J. 2003; 13: 3-13.

Krasaekoopt W, Bhandari B, Deeth H. The influence of coating materials on some properties of alginate beads and survivability of microencapsulated probiotic bacteria. Int Dairy J. 2004; 14: 737-743.

Lee JS, Cha DS, Park HJ. Survival of freeze-dried Lactobacillus bulgaricus KFRI 3673 in chitosancoated calcium alginate microparticles. J Agr Food Chem. 2004; 52: 7300-7305.

Mandal S, Puniya AK, Singh K. Effect of alginate concentrations on survival of microencapsulated Lactobacillus casei NCDC-298. Int Dairy J. 2006; 16: 1190-1195.

Muthukumarasamy P, Allan-Wojtas P, Holley RA. Stability of Lactobacillus reuteri in different types of microcapsules. J Food Sci. 2006; 71: M20-M24.

Pan LX, Fang XJ, Yu Z, Xin Y, Liu XY, Shi LE, et al.. Encapsulation in alginate-skim microspheres improves viability of Lactobacillus bulgaricus in stimulated gastro-intestinal conditions. Int J Food Sci Nutr. 2013; 64: 380-384. 
Picot A, Lacroix C. Encapsulation of bifidobacteria in whey protein-based microcapsules and survival in simulated gastrointestinal conditions and in yoghurt. Int Dairy J. 2004; 14, 505-515.

Shah NP. Functional cultures and health benefits. Int Dairy J. 2007; 17: 1262-1277.

Sheu TY, Marshall RT. Microentrapment of lactobacilli in calcium alginate gels. J Food Sci. 1993; 58: 557-561.

Shi LE, Li ZH, Li DT, Xu M, Chen HY, Zhang ZL, et al. Encapsulation of probiotics Lactobacillus bulgaricus in alginate-milk microspheres and evaluation of survival in simulated gastrointestinal conditions. J Food Eng. 2013a; 117: 99-104.

Shi LE, Zhang ZL, Song YQ, Zhou ML, Yu WM, Tang ZX. Encapsulation of Lactobacillus bulgaricus in carragenan-locust bean gum coated milk microspheres with double layer structure, LWT-Food Sci Technol. 2013b; 54: 147-151.
Sultana K, Godward G, Reynolds N, Arumugaswamy R, Peiris P, Kailasapathy $K$. Encapsulation of probiotic bacteria with alginate-starch and evaluation of survival in simulated gastrointestinal conditions and in yoghurt. Int J Food Microbiol. 2000; 62: 4755.

Tang ZX, Huang XQ, Baxi S, Chambres JR, Sabour PM, Wang Q. Whey protein improves survival and release characteristics of bacteriophage Felix O1 encapsulated in alginate microspheres. Food Res Int. 2013; 52: 460-466.

Hansen LT, Allan-Wojtas PM, Jin YL, Paulson AT. Survival of Ca-alginate miecoencapsulated Bifidobacterium spp. in milk and simulated gastrointestinal conditions. Food Microbiol. 2002; 62: 47-55.

Received: September 09, 2013; Accepted: January 13, 2014. 